\title{
What does political economy tell us about economic development - and vice versa?
}

\author{
Philip Keefer \\ Development Research Group \\ The World Bank \\ 1818 H St. NW \\ Washington, DC 20433 \\ pkeefer@worldbank.org
}

Forthcoming: Annual Review of Political Science

The generous and insightful comments of Jeffry Frieden, Margaret Levi and Matthew

Shugart are gratefully acknowledged.

\begin{abstract}
This essay reviews how three pillars of political economy, collective action, institutions and political market imperfections, help us answer the question: why do some countries develop and others not? Each makes tremendous advances in our understanding of who wins and who loses in government decision making, generally, but only a subset of this literature helps us answer the question. The study of political market imperfections strongly suggests that the lack of credibility of pre-electoral political promises and incomplete voter information are especially robust in explaining development outcomes. From the institutional literature, the most powerful explanation of contrasting development outcomes links political checks and balances to the credibility of government commitments.
\end{abstract}

World Bank Policy Research Working Paper 3250, March 2004

The Policy Research Working Paper Series disseminates the findings of work in progress to encourage the exchange of ideas about development issues. An objective of the series is to get the findings out quickly, even if the presentations are less than fully polished. The papers carry the names of the authors and should be cited accordingly. The findings, interpretations, and conclusions expressed in this paper are entirely those of the authors. They do not necessarily represent the view of the World Bank, its Executive Directors, or the countries they represent. Policy Research Working Papers are available online at http://econ.worldbank.org. 


\section{What does political economy tell us about economic development - and}

\section{vice versa?}

The problem of underdevelopment is in substantial measure one of government failure, and therefore political failure, in developing countries. A vast literature has illuminated the role of interest groups, institutions and political market imperfections in shaping the actions of government. However, there has been no systematic effort to establish how the political economy literature answers the question, "Why are some countries economically developed and others not?" Addressing this question is the objective of this essay.

Two government failures are the focus of this essay. One is the adoption of policies that unnecessarily leave most people in society worse off. ${ }^{1}$ The other is the inability to make credible promises to refrain from opportunistic behavior. ${ }^{2}$ The first, policy inefficiency, has been examined using each of the three pillars of political economy analysis. The theory of collective action rests on the hypothesis that organized groups of voters apply more pressure on politicians than unorganized groups. This theory explains systematic policy failure in developing countries if special interests in poor countries are particularly well-organized and antagonistic to broader development objectives.

The second pillar focuses on the institutions that structure how politicians gain and retain power and who can propose or must approve policy change. This explains

\footnotetext{
1 "Unnecessarily" in the sense that Pareto-superior policies, policies that made some better off without making others worse off, could in principle have been adopted.

2 The two failures are linked, since government credibility influences policy choice. Governments that know their promises regarding the future are not credible have less incentive to undertake policies that only bear fruit if citizens believe government promises regarding the future. A third significant category of government performance relates to redistribution and inequality. These enter the analysis below as a puzzle, because of the absence of massive redistribution in highly unequal countries where the poor majority can and do vote; and as an explanation, because a significant literature links the failure of some countries to develop precisely to initial conditions of significant inequality in society.
} 
development if the formal institutions of poor countries yield greater inefficiencies in policy making than formal institutions in rich countries. Finally, policy distortions may be driven by imperfections in political markets, including the lack of voter information; the lack of credibility of pre-electoral political promises; the "all or nothing" nature of many political choices (such as the need to choose a single candidate to represent voter interests on multiple dimensions); and the extent of polarization in the electorate across politically relevant dimensions. If these imperfections are more pronounced in less developed countries, they can explain differential development outcomes.

The second government failure - the inability to make credible commitments handcuffs governments in numerous ways, from monetary policy to their ability to encourage investment. The literature here is more recent, but tends to focus as well on the relative size and power of economic interests in a country, formal institutions, particularly the extent of political checks and balances and the voting franchise, and political market imperfections, particularly the inability of politicians to make credible pre-electoral promises. Researchers in this area, more than in any other, attempt to explain divergent experiences of economic development, and argue explicitly that governments in poor countries are less able to make credible commitments.

This review sidesteps discussion of the determinants of policy efficiency in autocracies, simply because the literature on the political economy of democracies is far more advanced. However, the entire debate surrounding the sources of government credibility implicitly contrasts autocratic forms of government, with no elections and no political checks and balances, with governments that exhibit these institutional features. Similarly, following the literature, the discussion below relies heavily on cross-country statistical comparisons to make the case that particular political economy features promote 
development or not. At the same time, in making the case that electoral systems or interest group characteristics in fact drive political behavior in particular ways, relatively more evidence is drawn from research in Latin America, where scholars have been especially active in linking formal institutions and political decision making. Finally, although the discussion here has implications for the political economy of reform, that large and important literature is also not directly considered.

The conclusion of the essay is straightforward to foreshadow. All the strands of political economy analysis have dramatically improved our ability to understand the determinants of government decision making. Only a subset of the literature, however, so far offers a convincing explanation for development. Within the literature on institutions, analyses of checks and balances among political decision makers provide the most robust explanation. Analyses of imperfections in political markets, particularly information and preelectoral credibility, offer another useful perspective to understand development. Other analytical levers from the political economy literature provide less help in understanding why some countries are developed and others are not.

\section{Variations in government performance and economic development}

Countries exhibit enormous variation both with respect to their policy choices and their credibility. With respect to policy efficiency, taking into account per capita income, average secondary school enrollment in 154 countries in 1995 varied more than 100

percentage points from the minimum to the maximum. ${ }^{3}$ Enrollments in the top 25 percent of countries were more than 34 percent higher than the bottom 25 percent. One commonly used measure of credibility is an indicator of the rule of law. On a six point scale, again

3 That is, first ask: what is the policy we expect given the country's income? Then subtract the actual policy from the predicted policy. This difference or residual gives the policy of a country holding constant the effects of income. A positive residual means that actual policy is better than what one might have expected on the basis of income; a negative difference means that actual policy is worse. 
controlling for per capita income, the lowest scoring 25 percent of countries scored more than one point below the best performing quartile. Similarly, the most corrupt quartile of countries was more than 1.5 points more corrupt than the least corrupt quartile, again on a six point scale. ${ }^{4}$ Taking policy and credibility failures together, it is not surprising that from 1975 to 2000, income per capita in the fastest growing quartile of countries grew more than two percentage points per year faster than in the slowest growing quartile - a difference that, by the year 2000, meant that the incomes per capita in the slower growing quartile were more than 60 percent less than they otherwise would have been. ${ }^{5}$

One could argue that these discrepancies, even controlling for income, are outside government control. Many factors enter into school enrollments that are unrelated to government policy; this is even more true with respect to growth. However, again controlling for income per capita, the top quartile of countries spent more than 7 percentage points more on education, as a fraction of total government spending, than the lowest spending quartile. ${ }^{6}$ It may not be surprising, therefore, that if one simply correlates growth across countries and asks how poor countries are doing relative to rich countries, one finds that divergence between the two groups is increasing (Pritchett 1997). These differences are a core puzzle of the social sciences.

\section{Collective action: economic interests and the shaping of government policy}

Why are some economic interests better able to impose their preferences on government policy than others? Olson's (1965) work answered this question with the argument that those economic interests least able to overcome collective action problems in

\footnotetext{
4 Income, growth and school enrollment data from the World Development Indicators. Rule of law and corruption data from Political Risk Services’ International Country Risk Guide.

5 Income and school enrollment data from the World Development Indicators. Rule of law and corruption data from Political Risk Services' International Country Risk Guide.

${ }^{6}$ Education spending from the World Development Indicators.
} 
order to project their demands on politicians are most likely to bear the costs of political decision making. The influence of a group depends not only on the economic gain or loss that a group might incur from government action, but also on the size of the group's membership and its organizational ability. Hardin (1982) further elaborates on this theme to analyze the informational and other barriers to collective action.

The notion that economic interests matter for policy has been a mainstay of research into policy change in the United States. McGuire and Ohsfeldt (1987) find that slaveholding voters at state-level constitutional assemblies resisted constitutional provisions that gave greater authority to the national government and, thereby, to the majority non-slaveholding northern states. Romer and Weingast (1991) show that Congressional votes concerning the US savings and loan crisis were significantly determined by whether legislators' voting districts - the key institutional variable - were dominated by solvent or insolvent thrift institutions. In his analysis of Congressional action regarding various international financial crises, Broz (2002) finds that legislators from districts with many low-skilled workers were most likely to oppose international financial bailouts (e.g., loans to Mexico to stave off its default). His research suggests that emergency responses to international crisis that appear driven by executive branch decision making are in fact not at all immune from the usual factors of legislative politics. Finally, Kroszner and Strahan (1999) address the puzzle of a change in a regulatory status quo that had persisted for decades: the prohibition against branch banking. They link the sudden softening of small bank opposition to laws allowing large banks to set up branch banks to a technological innovation, the introduction of automated teller machines.

Bates (1981) pioneered the application of collective action theory to policy outcomes in developing countries. He linked agricultural policies in some countries in Africa - a mix 
of harsh price controls on agricultural outputs administered by monopsony marketing boards and generous direct and indirect subsidies on imported inputs - precisely to the differential influence of interest groups on politicians. In contrast to the work in American politics, he focused on the characteristics of the interest groups themselves. He argued that these policies could be directly traced to the inability of small farmers, who used few of the imported inputs, to organize effectively; to the successful collective action of relatively few large farmers to receive input subsidies that offset the price controls; and to the need to subsidize food purchases of urban residents because of the relative ease with which they could be mobilized politically in opposition to the government. This and other contributions, in both developed and developing countries, leave little doubt that organized interest groups have significant advantages in the making of policy.

Research based on the theory of collective action has not often asked why some countries consistently pursue more welfare-enhancing policies than others, however. Three possibilities nevertheless emerge from Olson's work. One is crisis. Olson (1982), in Rise and Decline of Nations, argues that World War II upset the entire structure of interest groups in affected countries. With their organizational capacity in tatters and their links to authority severed, entrenched special interests were no longer able to exercise a "sclerotic" effect on economic policy making and growth. This book excited significant debate, admiring of the power of its parsimonious theory and sometimes skeptical about the historical evidence marshaled in support of the theory. However, there seems to be little scope for using crisis to explain the difference between developing and developed countries. Developing 
countries are among the most upheaval-prone in the world, but within these societies it is actually the best-organized interest groups that seem to be most resilient. ${ }^{7}$

Second, the sheer number of interest groups might influence their overall impact: multiple interest groups, competing for state attention, might offset each others' influence. Experience suggests otherwise, however. In conditions where interest groups are strong generally, governments tend to respond to interest group competition by arranging logrolls that give competing interest groups what they want at the expense of unorganized interests. Omnibus legislation emanating from the US Congress provides one frequent example of this. Bates (1981) concludes that in the African countries he examines, all special interests (large farmers, urban residents) were satisfied at the expense of unorganized interests (small farmers).

Finally, it might be that countries differ in the presence of well-organized groups with interests antagonistic to development. This is implicit in Frieden (1991). He explores the role of economic interests in the quite different responses of five Latin American countries to similar crises. Two hypotheses frame the argument: a particular economic sector can better influence government responses to crisis the greater is its internal cohesion; and a sector will invest more in exerting influence the more that it stands to gain or lose from policy change. The first is familiar. The second rests on the notion that sectors with assets that cannot be easily transferred to other uses - sectors with more specific assets - are those that have the most to gain from influencing policy. ${ }^{8}$ Bates (1983) similarly argues that

\footnotetext{
7 Despite the departure of the Suharto regime, the transition to democracy, and severe economic crisis, the former cronies of the old regime, special interests par excellence, continue to hold sway over privatization, deregulation and anti-corruption efforts of the country (Oxford Analytica Daily Brief, "Indonesia: Endemic corruption overshadows reform plans," 16 September 2003).

8 Oliver Williamson first described the problem of asset specificity as the potential that a firm could be held up by a trading partner because the firm's assets were useful only in producing goods to sell to that trading partner. Frieden's notion is somewhat different. Assets are specific when firms cannot use their assets outside
} 
the nature of production (in his case, cocoa in Ghana and cereal grains in Kenya) systematically influences producer incentives to act collectively or collusively.

Firms that derive large rents from natural resources, from government-established barriers to entry, or that are capital-intensive, with capital equipment useful only in the production of particular goods, have stronger interests in mobilizing. An important aspect of asset specificity is pre-existing government privileges to a sector. If there are high rents to production in a particular sector because of government privileges, and those privileges are not transferable to other sectors, then the assets of firms in the privileged sector are highly specific. However, Frieden explicitly abstains from explaining why more such privileges exist in some countries rather than others.

The work of Bates and Frieden carefully charts the role of interest groups in policy failures of developing countries. Their arguments are not meant to identify why the influence of interest groups is more pernicious in some countries than in others. However, their conclusion - that the characteristics of the economic activities in which interest groups are engaged is a significant determinant of interest group activity - is reflected in subsequent research that examines the relationship between the nature of economic interests in a society and economic development. Engerman and Sokoloff (2002) and Acemoglu, Johnson and Robinson (2002) observe first that economies differ systematically in the extent to which economic rents can be concentrated in a few hands. Some economies, such as those in many Spanish colonies in Latin America, relied on capital-intensive mineral extraction or plantation-style agriculture. Rents in other areas, such as many North American British colonies, could only be extracted through the efforts of large numbers of colonists as they worked in small agricultural plots or small manufacturing endeavors. 
Engerman and Sokoloff (2002) painstakingly demonstrate that Latin American and Caribbean countries based on plantation agriculture or mineral extraction generated a wide range of policy inefficiencies. Their argument, and that of Acemoglu and Robinson (2002), is that the early comparative economic advantage of these countries lay in economic activities that naturally concentrated wealth in a few hands. Political power followed economic power, and the politically powerful had no incentive to permit an even economic nor political playing field for citizens. They imposed high barriers to entry into manufacturing and finance, underprovided education, and limited the electoral franchise to a small slice of the citizenry. In the United States, in contrast, particularly the northern states, the nature of economic activity demand created a greater demand for skilled labor and the situation was precisely the reverse. Acemoglu, Johnson and Robinson (2002) look at similar facts but emphasize the second important government failure: the inability to make credible promises to citizens. This is discussed in greater detail in later sections.

Despite different emphases, the essential point in both Engerman, et al. and Acemoglu, et al. (2002) is that the initial allocation of rents discourages institutional developments that are conducive to growth and development. ${ }^{9}$ Institutions, then, rather than collective action theory, are the key link in their argument from economic interests to economic development. Though these researchers point to institutions such as the franchise and restraints on the executive, their work paints with a broad institutional brush. This naturally leads one to ask which institutions matter for development. The next section of this essay reviews some of the rich literature linking political and electoral institutions to political incentives to pursue efficient policies.

\footnotetext{
9 Rueschmeyer, Stephens and Stephens (1992) make a similar argument. The success of British colonies, generally (though not universally), they argue, was due to the lack of control of local elites over the colonial state. Why this lack of control prevailed is precisely what Engerman, Haber and Sokoloff and Acemoglu, Robinson and Johnson attempt to explain.
} 


\section{The institutional links from economic interests to economic policies}

The interest group literature is persuasive that policy inefficiencies tend to emerge

because politicians weight interest group objectives more heavily than those of the average

citizen of a country. Substantial progress has been made in understanding the circumstances

under which political competitors are more likely to appeal to citizens broadly or to special

interests narrowly. One branch of this research has focused especially on the analysis of

formal electoral and political institutions (e.g., parliamentary versus presidential forms of

government). ${ }^{10}$ To the extent that formal institutions are both different in developing than

in developed countries and can explain systematic policy failures in the first relative to the

second, they also can provide an explanation for divergent development experiences. ${ }^{11}$

To identify whether electoral and political institutions penalize politicians for

pursuing special interests at the expense of the national interest, one must first establish what

kinds of policies are generally associated with special or national interests. ${ }^{12}$ Most of the

work comparing the policy effects of formal institutions focuses on budget policies. Under

this rubric, the maintained assumption in the literature is largely that narrowly targeted

spending, with no positive spillovers to the wider population, favors special interests. Public

\footnotetext{
10 The label of "political" for those institutions that govern political decision making of officials already in government, and of "electoral" for those institutions that govern how officials get to office, is purely for expository convenience.

11 These are far from the only institutional debates in the political economy literature. For example, one of the core debates in American politics concerns the driving forces of Congressional organization: whether it is redistributive (matching committee membership to legislator demand for committee policies), as in Shepsle and Weingast (1987); informational (using committee influence to provide an incentive to legislators to become experts in areas of great uncertainty), as in Krehbiel (1991); or partisan (parties, rather than committees, are the vehicle through which legislators solve collective action problems), as in Cox and McCubbins (1993). This debate, usefully summarized in Shepsle and Weingast (1994), uses policy outcomes to establish which underlying motivations drive congressional organization, rather than using congressional organization to explain changes in policy. It therefore does not have direct implications for the institutions and development debate.

12 Shleifer, et al. (2003) argue for the primacy of institutions in economic development. However, their analysis concerns the difficulties societies have weaving between disorder and dictatorship. They abstract from the specific incentives of political decision makers to adopt laws and economic policies that they argue persuasively are key to economic development.
} 
good spending, or redistributional spending that benefits large segments of the population, do not. Other metrics for assessing whether politicians pursue the public interest or not are potentially preferable but are difficult to measure and test; hence, the focus in the literature on budgets.

So, for example, Cox and McCubbins (2001) argue that institutions influence the tradeoff between policies targeted at narrow or broad constituencies, depending on whether institutions give candidates incentives to develop personal constituencies or parties incentives to splinter. Persson and Tabellini (2000) distinguish electoral institutions in a slightly different way, asking whether they give politicians incentives to provide narrow or public goods, but also asking whether they moderate or exacerbate politician incentives to engage in rent-seeking. Milesi-Ferretti, Perotti and Rostagno (2002) analyze a third permutation: the incentives of government to provide group-specific or geographicallytargeted benefits.

\section{Electoral institutions}

Cox (1997) highlights three electoral institutions that influence policy tradeoffs between nationally- and narrowly-targeted policies. How many votes can voters cast? How large are district magnitudes? More votes and larger magnitudes increase incentives for parties to splinter. And, can voters express a preference for individual candidates? If so, candidate incentives to seek personal constituencies increase, even at the expense of their party and its orientation toward a broader constituency. Cross-country data confirm substantial variation with respect to some of these electoral institutions, and sharp differences between developing and developed countries. The more than 90 countries exhibiting competitive elections in 2000 were evenly split in their reliance on proportional representation or plurality electoral rules. However, among the poorest half of these 
countries (those with purchasing power parity - adjusted per capita incomes of less than $\$ 6,900)$, two-thirds used plurality systems. District magnitude varies similarly: the average district magnitude in poorer countries with proportional representation systems is 16 , but is 24 in richer countries. ${ }^{13}$

Other electoral differences also matter. Contributors to Mainwaring and Shugart (1997), looking at Latin American presidencies, observe that in Brazil and Argentina, directly-elected state governors, rather than national political leaders, select candidates. In Argentina, this leads to greater internal fragmentation of parties and reduced incentives to focus on the national interest than one might otherwise predict on the basis of its closed list PR system. It exacerbates party fragmentation in Brazil, whose open list PR system, low party thresholds and historically lax rules governing party alliances already promote the pursuit of narrow over broad interests. Colombia prohibits parties from denying the use of their party label to any list of candidates. Within one electoral district, therefore, competing lists can bear the same party label, again yielding greater fragmentation than would otherwise be the case, and therefore greater political incentives to focus on narrow rather than national interests.

The ratio of voters to legislators across electoral districts also affects the ability of some voters to impose costs on others. The upper legislative chambers of the Dominican Republic and the United States assign sparsely populated regions the same representation as heavily populated regions. California, with approximately 33 million people, has the same number of senators (two) as each of the 24 smallest states, which together have approximately 36 million residents. The Distrito Nacional of the Dominican Republic has

13 Elections in which there were multiple competing candidates or parties, more than one party contesting, and no candidate or party winning more than 75 percent of the vote. All of the information in this paragraph is from the Database of Political Institutions (see Beck, et al., 2001). 
28 percent of the electorate and one senator; the 16 smallest provinces each have one senator, as well, but together they have only 23 percent of the electorate. In India, the largest constituency of the lower house, the Lok Sabha, has 25,000,000 voters, while the smallest has only 50,000. In Canada's lower house, on the other hand, most electoral districts have between 90,000 and 100,000 voters; the smallest has 27,000 and the largest 115,000 , only four times larger. Voters in districts where this ratio is low have greater influence on legislation, all else equal, than voters where it is large. ${ }^{14}$ Lee (1997) shows that in the United States, small states receive a disproportionately large share of almost all nondiscretionary redistributive transfers, independent of need - despite the fact that the small state bias is only strong in the Senate.

Empirical evidence on the economic effects of voting rules is growing. Persson and Tabellini (2000) compare a majoritarian system (single member districts, party control over nominations, and a stylized parliamentary form of government) with a proportional system (single district, closed list, and party control over nominations). ${ }^{15}$ The winner-take-all rules in majoritarian systems forces competing political parties to focus exclusively on the swing (indifferent) voting constituency, leading them to promise fewer public goods (which benefit all constituencies) and more targeted goods (targeted exclusively at the swing constituency). Proportional systems extract a greater political cost from parties that attempt this strategy,

\footnotetext{
14 See Samuels and Snyder (2002) for a comprehensive analysis of malapportionment. They show, for example, that Argentine and Brazilian malapportionment are much worse than the Dominican Republic's. Some also consider the sheer number of legislators. Bradbury and Crain (2001), for example, find that government spending rises with the number of legislators, but that bicameralism dampens this effect. 15 Persson and Tabellini (2000) and co-authors have launched the most comprehensive effort in the literature to model and test the effects of different political and electoral institutions on public policy, particularly public spending. Many examples in this review are therefore drawn from their work, but often to contrast the assumptions they make about institutional rules with the actual rules scholars have analyzed in the comparative politics literature.
} 
though, because PR systems permit votes in the non-swing constituencies to influence control of the legislature.

Milesi-Ferretti, Perotti and Rostagno (2002) compare the same two voting rules, also assuming a stylized parliamentary form of government. They ask how a shift from more to less proportional electoral rules influences government incentives to target spending on homogeneous but geographically dispersed groups or on heterogeneous but geographically concentrated groups. Voters have no exogenous ideological predilections but have different preferences over geographic and non-geographically targeted goods. Following the logic of the "citizen candidate" model, as in Besley and Coate (2001), voters (not parties) choose candidates, depending on which candidate's preferences are more likely to yield spending outcomes that best match voter preferences. Consistent with Persson and Tabellini, they predict more geographically-targeted spending in majoritarian systems, and more grouptargeted spending in more proportional systems. Unlike Persson and Tabellini, they predict an ambiguous relationship between electoral rules and total government spending.

Based on these analyses, one can conclude that electoral rules matter for policy but almost surely do not explain why some countries develop and others do not. High vote thresholds provide an incentive for parties to coalesce and to prefer policies in the national interest relatively more. However, they are also an effective tool to exclude political upstarts from challenging existing parties that fail to perform, leading to more rent-seeking. In addition, countries tend to exhibit clusters of electoral institutions with offsetting effects. For example, low district magnitudes reduce party fragmentation, but they also encourage candidates to develop personal constituencies. 


\section{Political institutions}

Political institutions determine which politicians can set the agenda; which can veto proposed changes in law or regulation; and which can force other politicians to leave office or to seek re-election. The stronger are the veto and agenda-setting powers of political decision makers with broader and more national constituencies, and the less vulnerable such politicians are to expulsion by the other decision makers, the more that policy will reflect national rather than narrow interests.

These institutions vary substantially across countries. The relative authority of the executive and legislative branches over the budget differs from country to country (see Hallerberg and von Hagen 1999). In Chile and many other Latin American countries, only the president can propose the national budget and the legislature has tightly restricted amendment powers. In the United States, in contrast, only the House of Representatives can originate a spending bill and the president has no powers of amendment. The authority that each branch of government wields directly over the tenure of the other also varies. Some countries' presidents can call new elections for the legislature (e.g., Russia), while most cannot. In some countries, legislatures can bring down the government without having to go through new elections (e.g., in Italy); in other countries, the desire to replace a cabinet requires legislators to bear the risk of new legislative elections, with significant consequences for legislative cohesion (Huber 1996, Diermeier and Fedderson 1998).

Presidential and parliamentary systems incorporate different bundles of institutional arrangements governing the assignment of veto and agenda-setting power and the control of the executive and legislature over each other's electoral destinies. At the same time, a far greater fraction of poorer democracies is presidential. ${ }^{16}$ The large literature distinguishing

\footnotetext{
16 The more than 90 countries exhibiting competitive elections in 2000 were evenly split between the two
} 
parliamentary and presidential systems therefore provides a convenient way to evaluate the policy and development impact of these bundles. ${ }^{17}$

Persson, Roland and Tabellini (2000) ask how the change from a presidential to parliamentary form of government affects public good provision that benefits all citizens, narrowly targeted policy making that benefits small groups of citizens, and rent-seeking, that benefits policy makers themselves. They assume that both systems employ majoritarian electoral rules (single member districts) and that parties enjoy complete control over candidate selection and policy stances. Parliamentary systems are cabinet governments in which cabinet members have exclusive, all-or-nothing proposal power over their portfolios, where one portfolio relates to spending and the other to taxation. Each cabinet member is entitled to veto the proposals of all other cabinet members. Veto, however, leads to the collapse of the cabinet and the potential loss of this veto power by all cabinet members. Mutual veto power allows the cabinet members to make credible agreements with each other.

In presidential systems, they assume that all proposal power rests with the legislature (the executive can make no amendments, but can only disapprove or approve the final package), and proposal power within the legislature is dispersed, as in the cabinet. ${ }^{18}$ However, the committee in charge of tax proposals cannot veto the proposals of the systems; almost 75 percent of the poorer countries in this group were presidential.

17 There is a lively debate about whether presidential systems are less stable or more susceptible to gridlock, which is not the focus of the argument here. For contributions to this debate, see Linz and Valenzuela (1994), who argue against presidentialism, and Shugart and Mainwaring (1997), who suggest that the vast differences in the electoral rules and level of party discipline among presidential systems make sharp conclusions about the role of presidentialism in stability, gridlock and capricious decision making more difficult to detect. Cheibub and Limongi (2002) argue as well that political instability need not be correlated with political system, in no small measure because they find that a core assumption that is thought to drive greater stability in parliamentary systems - majority control of both executive and legislature - frequently fails to hold; 22 percent of parliamentary regimes they examine had minority governments.

18 They also analyze a variant, in which the president can propose the size, but not the allocation, of the budget, yielding the same results. 
spending (appropriations) committee, and vice versa. The two committees therefore have no capacity to make credible agreements with each other. Proposals are rejected only if a majority of the legislature votes them down.

The differences in credibility drive the different outcomes in the two systems. Because the tax committee in the presidential system cannot veto the spending committee's proposed allocation of spending, it knows that it will have to accept a lower spending allocation to its own constituents than it would otherwise be able to extract. As a consequence, the tax committee sets taxes very low. This drives rent-seeking and targeted transfers to specific voters down to zero, but also severely reduces public good provision. In parliamentary systems, though, the institutional set-up guarantees the tax minister that he will get a large allocation, so he proposes a high tax rate. Public good provision, targeted transfers to specific groups of voters and rent-seeking are all high.

The Persson and Tabellini analysis is the most rigorous in linking characteristics of presidential and parliamentary systems to policy outcomes. However, it makes a number of assumptions and emphasizes a number of institutional characteristics that other analysts do not. Do these differences matter? For example, Shugart and Carey (1992) abstract from the separation of powers argument and argue that the key distinction between presidential and parliamentary systems is that voters can cast a separate vote for the "national" policy maker in presidential systems, while parliamentary systems compel them to bundle their votes for the national policy maker and the legislator in a single ballot. Voters are therefore more likely to oblige legislators in parliamentary systems to pursue a broader focus in policy making, giving less prominence to particularistic issues. Persson and Tabellini incorporate this difference in their institutional set-up, in fact, but it does not turn out to drive their policy results. 
Persson, Roland and Tabellini (2000) assume presidents can only veto spending bills and show that this veto power has no effect at all on final outcomes. Shugart and Haggard (2001) look at 23 presidential systems and find that in seven of them presidents enjoy exclusive proposal power over spending legislation and the legislature confronts severe constraints on amending presidential proposals.

They also assume that legislative committees in presidential systems cannot make credible agreements with each other. However, legislative leadership (Cox and McCubbins 1993) or a rules committee (Huber 1992) have been found to enforce inter-committee agreements. ${ }^{19}$ Huber (1992) argues that closed rules in France and the United States - the ability to ensure that bills out of committee are discussed by the plenary with no amendments permitted - are precisely used to preserve the credibility of bargains between parties.

If one modifies the postulated institutional arrangements in Persson, Roland and Tabellini (2000) to reflect these real-world variations, how do spending predictions change? Presidential agenda control generates precisely the same conclusions regarding low spending, as long as presidents cannot make credible promises to legislatures. Absent credibility, legislators do not believe presidential promises that spending will be directed to areas of legislator concern; they therefore refuse to approve high taxes. However, where the agendasetting spending committee prefers targeted benefits to its narrow constituency and low public good spending, shifting agenda-control to the president should dramatically increase public good spending and reduce targeted spending.

19 Krehbiel (1996) argues that the legislative leadership in the US House of Representatives has relatively weak influence over policy making, though his case concerns possible conflicts between the median voter of the House and the median committee voter rather than conflicts between committees. 
If the president does not enjoy agenda control, but the legislature has solved the inter-legislator credibility problem, the core reason for low spending in presidential systems disappears. Spending outcomes should look similar to parliamentary systems, both with respect to levels and allocation across public and private goods. Indeed, analysts of Latin American presidential systems point to the significant use of pork as the vehicle with which presidents drive through their legislative agendas (Shugart and Haggard 2001).

Parliamentary systems are also heterogeneous. For example, there is substantial variation across parliamentary systems in the rules governing the vote of confidence, which play a crucial role in policy outcomes in the hypothesized parliamentary system. If a vote against the government's bill means the government falls, then as Diermeier and Fedderson (1998) argue, the ruling coalition can more aggressively target its own constituencies at the expense of those outside the coalition. The premise in such models, however, is that any member of the ruling coalition can make an issue a confidence vote and be sure that the government will adhere to its results.

Empirically, however, of the 18 OECD parliamentary democracies with votes of confidence that Huber (1996) considers, in only six is it written into the constitution. Elsewhere it is based on convention or standing orders of parliament, creating few formal legal obstacles to ignoring the vote of confidence. Moreover, in every country with a vote of confidence procedure, it is the prime minister who must propose that a vote on a bill be a confidence vote (Huber 1996). This centralizes proposal and veto power in the hands of the prime minister rather than of individual ministers with line portfolios. The line ministers cannot make all-or-nothing offers that benefit their narrow constituencies, as in the model of Persson and Tabellini. It is rather the prime minister, who presumably has broader interests 
at heart, and would prefer less targeted public spending, as in presidential systems, rather than more.

The heterogeneity of presidential and parliamentary systems, over important institutional dimensions (such as the agenda control of presidents, the ability of legislators and presidents to make credible commitments, and the binding nature of the vote of confidence) cloud our ability to conclude that presidential systems pursue different policies, which are worse for development. It therefore follows that the mere fact that developing countries are more likely to have presidential forms of government is unlikely to be a key factor to explain slow development.

\section{Assessing the empirical evidence of the policy effects of legislative and political institutions}

A growing literature finds that presidential systems spend much less than parliamentary systems (Persson, Roland and Tabellini 2000). This is a robust finding. The likely explanation for it, emerging from the foregoing discussion, is that presidents are unable to make credible commitments to legislators about how money will be spent, making legislators reluctant to approve high taxes. ${ }^{20}$ There is less empirical support for the hypothesis that regime choice influences the allocation of government spending. Keefer (2003a) finds no evidence of a systematic effect of regime type on several dimensions of government performance, including gross secondary school enrollment and public investment. Persson and Tabellini (1999) themselves do not find strong evidence that broad-based spending is proportionately less and targeted spending proportionately more in presidential than in parliamentary systems.

\footnotetext{
20 This argument is more plausible than the alternative - that legislators in presidential systems cannot make credible agreements with each other - since legislators in fact appear to be perfectly able to make such agreements.
} 
What explains the inconsistency that presidential systems spend less, as predicted, but not differently, as also predicted? One possibility is variations in electoral institutions within presidential systems. Scholars who have studied presidential countries have documented a strong predilection for pork (targeted spending), which the earlier theories predict should be greater in parliamentary systems. This work blames pork on electoral rules and weak party discipline. Ames (1995) attributes overwhelming concern for pork (constituency-specific projects) among Brazilian legislators to the open-list legislative system in place there, but finds as well that larger district magnitudes attenuate this effect, as one might expect (since in large districts it is more difficult for single legislators to take credit for projects). The role of governors in Argentine politics obliges politicians to target state-level rather than national-level priorities (Jones, Sanguinetti and Tommasi 2000).

Cross-country tests of the effects of electoral rules on spending allocation are more ambiguous, however. Persson and Tabellini (1999) find that low district magnitudes drive political competitors to satisfy smaller constituencies. As a consequence, broad public goods (defined as expenditures on transportation, education, and public order and safety) are lower in these countries. Using similar measures of electoral institutions, Keefer (2003a) finds little effect on spending allocation, however, either of district magnitude or of electoral rule. Moreover, Milesi-Ferretti, et al. (2002), using by far the most sophisticated measures of proportionality, find strong evidence that more proportional systems in the OECD (which in the Database of Political Institutions district magnitudes of 20 in 2000, on average) generate bigher transfers to non-geographic groups than plurality systems (with district magnitudes of five). However, they do not find that geographically targeted spending is lower in more proportional systems, nor are they able to replicate their results for the Latin American sample. 
Assessments of the effects of electoral rules on rent-seeking are similarly mixed. Persson, Tabellini and Trebbi (2003) marshal substantial evidence that majoritarian electoral rules deter corruption. They use the Particularism database (Seddon, et al. 2003) for their institutional measures. Keefer (2003a), using institutional data from the Database of Political Institutions (Beck, et al. 2002) and different controls, finds contrary results. The empirical results mirror the inconsistencies in the theoretical arguments linking electoral rules to corruption. Majoritarian systems increase corruption if political promises prior to elections are not credible; they reduce it if promises are credible, or if voters use elections to make judgments on candidate competency (that is, plurality voting rules give voters greater ability to influence individual candidates' careers, hence the term “career concerns models”).

There is little doubt that electoral institutions influence government behavior. However, the evidence is not clear on the direction of the effect. Nor does the evidence support the claim that electoral institutions explain why politicians in developing countries are systematically more prone to the pursuit of policies benefiting narrow and private interests.

\section{Economic interests, institutions and the credibility of government commitments}

Together, the arguments so far reviewed make clear that the structure of interest groups and institutions establish "who gets what" in a society, but do not offer robust explanations for differences in levels of economic development. However, a significant literature argues that economic interests and institutions affect growth not simply because of their effect on policy, but because of the ability they give policy makers to make credible policy commitments.

The most important of these commitments is to refrain from expropriation, direct or indirect, a problem placed at the center of the study of development by North (1981). 
Ample evidence supports the weight given to this issue. For example, a puzzle emerges in Bates' work on Africa: why did governments set expropriatory tax rates so high that farmers actually stopped producing? McMillan (2001) argues that the governments studied by Bates could not promise not to expropriate - their horizons were too short and their incentives to engage in opportunistic behavior too great for farmers to believe that low tax rates, if imposed, would have persisted into the future. As a consequence, governments could not reap gains from reducing tax rates.

Further evidence on the point comes from year 2000 values of a widely used measure of the security of property rights from Political Risk Services, the "rule of law". It was nearly one standard deviation lower in countries below the median country's income per capita than above it. Keefer and Knack (1997) find that poor countries with insecure property rights not only fail to "catch up" to rich countries, but they fall further behind they "diverge." This evidence is not simply an indictment of redistributive government. In fact, the correlation between the Political Risk Services Rule of Law measure and the size of government (where size of government is an indicator of the extent to which government taxes citizen assets) is significantly negative (-.35 in 1997).

Nor should these results be taken to reflect the development impact of the predictability or stability of government decision making, rather than its credibility. As Tsebelis (1995) argues, policy stability should be high when the set of policies that politicians prefer to the status quo is small, but low otherwise. The work of Tsebelis and others precisely examines the stability effects of different institutional arrangements. Credibility, though, refers to how reliance on politician promises today creates an incentive for politicians to change policy opportunistically tomorrow. For example, US tax policy is not particularly predictable or stable - it changes regularly and often substantially. However, it is credible: 
entrepreneurs can rely on the fact that if they invest according to the dictates of the tax code today, the mere fact of their reliance will not trigger an opportunistic change in the tax code tomorrow. ${ }^{21}$

The predictability versus credibility attributes of institutions links to a classic dichotomy articulated by Cox and McCubbins (2001) when they distinguish institutions according to whether they lead governments to be indecisive or irresolute. The credibility (resoluteness) of institutions can conflict with the decisiveness of institutions in the face of crisis, creating ambiguity about the net effect of such institutions on development outcomes. Shugart and Mainwaring (1997) argue, for example, that Latin American governments exhibit a tendency towards gridlock. Keefer and Knack (2002b) look at the effect of political checks and balances, the institutional characteristic most often associated with credibility and gridlock, on country credit ratings. If decisiveness matters most to lenders, because they want to be sure countries will repay loans even in times of crisis, then checks and balances should have a negative impact on credit ratings. If resoluteness matters most, because lenders also want to be sure countries honor their loan commitments, checks and balances should matter positively. In fact, checks and balances significantly increase credit ratings.

How governments achieve credibility remains an unsettled question. Considerable attention has, however, been dedicated to the role of political checks and balances, which make it difficult for any one political actor to act unilaterally toward citizens, and the

\footnotetext{
21 Keefer and Stasavage (2003) present another example that makes this point. On a single policy dimension, under majority rule and with all voters perfectly informed, policy is always stable at the median voter's most preferred outcome. This stable policy outcome, however, need not be credible. The median voter could easily prefer a law that protects foreign investment in one period and then, once investment enters, could prefer a law that expropriates that investment. If policy were credible, foreign investors would respond vigorously to the first period decision not to expropriate and invest heavily. Since it is not, their investment response to the decision is muted or zero.
} 
universal franchise and competitive elections. It happens that these two institutional arrangements together encompass the most usual definitions of democracy.

North and Weingast (1989) argue that interest rates charged to the English Crown following the Glorious Revolution declined because of the enhanced power of the Parliament to prevent the British monarch from reneging on sovereign obligations. ${ }^{22}$ Henisz (2000) develops an indicator of the number of veto players, weighted according to the heterogeneity of their policy preferences, and finds that it predicts measures of property rights insecurity and that it is significantly related to economic growth. This indicator matches closely the fragmentation of political parties in a country. A different measure of checks and balances, from the Database of Political Institutions, is also a robust predictor of economic growth, operating on growth through its effect on the security of property rights (Keefer 2003b).

A central argument in the literature on monetary economics is that non-credible governments, unable to commit to a promise not to implement a surprise expansion of the money supply, are less likely to hold down inflation. Keefer and Stasavage (2003) demonstrate that checks and balances provide that credibility, constraining opportunistic behavior in the setting of monetary policy. Keefer and Knack (2003) show that checks and balances are key to controlling credibility-related distortions in another policy area, public investment. These arguments and those of North and Weingast make clear that credible commitment is not necessarily neutral with respect to the quality of economic policy:

\footnotetext{
22 Sussman and Yafeh (2002) dispute these conclusions, however, arguing that neither movements in interest rates nor the evolution of the volume of British government debt can be traced to the effects of the Glorious Revolution. Stasavage (2003) revisits the Glorious Revolution and concludes that parliament only constrained opportunistic behavior by chance and gradually, when the minority of parliamentary members who favored honoring sovereign obligations were able to make a deal involving religious freedom with those who were less favorable.
} 
without credible commitment, sound monetary policy and adequate public investment are more difficult to achieve.

Acemoglu and Robinson (2001) and Acemoglu, Johnson and Robinson (2002) reprise the question raised by Bates' work: why do politicians allow inefficient policies to persist when they would have more resources at their disposal if they eliminated them? Their answer to the question focuses on the implications of elections and the franchise. Expansion of the franchise gives the non-elite majority the opportunity to guarantee their own property rights, but also to expropriate the elite. Where initial inequality in the distribution of assets is high, and where the threat of rebellion is low, the elite has more to lose from expanding the franchise and refrains from doing so. Where the economic wellbeing of elites depends to a great extent on investment by the non-elite rather than on the exploitation of mineral resources or plantation agriculture, they prefer to expand the franchise. In doing so, the elite makes credible their promise not to expropriate non-elites, securing property rights and promoting economic growth.

Several questions suggest room for further research into the role of checks and balances and the universal franchise in allowing credible commitments by government. First, the security of property rights varies significantly across countries that exhibit political checks and balances. The rule of law in half of all countries exhibiting either checks and balances or competitive elections in the 1990s was the same or worse as in the median country lacking either one or the other. ${ }^{23}$ Second, most measures of democracy do not exhibit a robust relationship to growth, and yet most democracy measures focus on precisely the extent to which countries have competitive elections, a universal franchise and, in many cases, restraints on the discretion of the executive (checks and balances).

23 The rule of law measure is from Political Risk Services' International Country Risk Guide and the measures of checks and balances and competitive elections from the Database on Political Institutions. 
Przeworski, et al. (2000) make this point emphatically with their election-based objective measure of democracy. Keefer (2003b) demonstrates that checks and balances, but not another objective measure of competitive elections, from the Database on Political Institutions, nor subjective measures of democracy, from Freedom House and Polity IV, are significantly associated with growth. Mulligan, Gil and Sala-i-Martin (2003) argue that the only systematic policy difference between democracies and non-democracies is the expenditures of the latter to suppress political competition.

Third, despite adverse economic endowments, Latin American countries eventually did develop the institutions, especially the universal franchise, that researchers claim protect the property rights of non-elites rights. Nevertheless, despite the correction of these institutional distortions in the $20^{\text {th }}$ century, sustained growth did not emerge. ${ }^{24}$

Fourth, theoretical models in the literature contemplate two straightforward institutional alternatives (limited versus universal franchise, for example). There are, however, a variety of ways in which an elite can bring the non-elite into power without jeopardizing the elite's control of its own assets. For example, allowing a popular vote for one legislative chamber, but not another, the system prevailing in the United States in the nineteenth century, gave the average citizen some ability to block special interest efforts to accrue excessive privileges, while giving elites a way to veto efforts to redistribute their wealth. $^{25}$ Similarly, the military government in Chile enshrined an electoral system and a legacy of military senators in the constitution that together limited the ability of

\footnotetext{
24 Acemoglu and Robinson (2002) do argue that in highly unequal countries, where democracy leads to redistribution, there is a strong incentive for the rich to restore autocratic government; democracy does not stabilize. However, although Latin America is highly unequal and democracy has been unstable, in only one country, Chile, was the suppression of an elected government related clearly to (if not fully explained by) the strong redistributionist tendencies of the government.

25 The fact that these legislative institutions did not necessarily work in this way is the subject of the subsequent sections of the essay.
} 
redistributionist political forces from controlling economic policy following the restoration of democratic government. Why have more elites not tried to provide such institutional guarantees, accomplishing the goal of securing property rights for all but insulating the elites from the threat of redistribution?

One way to resolve these puzzles is to examine the underlying imperfections in political markets that might distort politician incentives. Even when the franchise is universal, institutional checks and balances are pervasive, and veto players have divergent interests, these imperfections may lead veto players to conclude that there is little electoral payoff to exerting effort on behalf of citizens whose rights are jeopardized by the government. These same political market imperfections seem to explain systematic policy differences between poorer and richer countries.

\section{Imperfections in political markets-credibility and information as explanations for policy failures in developing countries}

Of the many imperfections in political markets that scholars have identified, this essay closes with a discussion of just two, credibility and information. Embedded in the models discussed in the foregoing analyses are assumptions about the extent to which voters have information about candidate characteristics or performance and to which voters can believe the pre-electoral promises of candidates. Lack of either makes it more difficult for voters to hold candidates responsible for poor performance. Information and credibility imperfections encourage political actors to focus on a narrow group of constituents to the exclusion of all other citizens, or to ignore voters altogether. ${ }^{26}$ The impact on policy predictions can be significant. Persson and Tabellini (2000) show that majoritarian electoral

\footnotetext{
26 Information solves an important problem in models of gridlock: why do two veto players delay coming to an agreement that would make them both better off? In Alesina and Drazen (1991)argue that delay gives both sides information about the other side's willingness to tolerate crisis, and therefore a potential advantage in any final settlement that offsets the benefits of early agreement.
} 
systems are less corrupt when promises are credible, since majoritarianism forces candidates to compete more fiercely with each other in the swing district. They are more corrupt when promises are not credible, because they force voters to compete more fiercely with each other for benefits from governments.

\section{Imperfect information in electoral markets}

One branch of the information literature focuses on voters who are uninformed about candidate characteristics. These voters' decisions are swayed by political campaigns and advertisements, creating a role for special interests to purchase narrowly targeted policies by providing campaign finance (Baron 1994 and Grossman and Helpman 1996). One policy consequence is that uninformed voters are simply less well-served by government. In addition, governments accountable only to uninformed voters can be more vigorous in the pursuit of their own private interests. Because uninformed voters cannot easily identify the effect of rent-seeking on their welfare, politicians have greater scope to extract rents (Persson and Tabellini, 2000). Adserà, Boix and Payne (forthcoming) document exactly this: corruption is significantly higher in countries with lower newspaper circulation. The effects of newspaper circulation extend similarly to the security of property rights (Keefer 2003b). Newspaper circulation is dramatically lower in poorer countries than in richer.

In other approaches, voters prefer to choose the most "competent" candidate but are imperfectly informed about candidate competency. Under these circumstances, officials bias resource allocation against those public goods whose outcomes are more noisy and harder to use to assess politician ability and toward those that are better signals of high ability (Mani and Mukand 2002). They would, for example, favor construction over education. 
Finally, evidence suggests that when voters are informed about particular policies they are able to extract greater resources and better performance from political agents. Strömberg (2001) demonstrates that between 1933 and 1935, federal assistance to lowincome households in the United States was greater in those counties where more households had radios and were thus more likely to be informed about government policies and programs. Besley and Burgess (2003) document that state governments in India are more responsive to declines in food production and crop flood damage via public food distribution and calamity relief expenditure when newspaper circulation, particularly in local languages, is greater. This evidence does not inform the broader question of whether policy is more socially beneficial when voters are more informed, however. ${ }^{27}$

\section{Lack of credibility in electoral markets}

The ability of politicians to make credible pre-electoral promises also provides a persuasive explanation of why policy failures are more likely in some countries than in others. When campaign promises are not credible - when it costs election winners little to abandon them - electoral competition does little to spur politician incentives to satisfy constituents. In young or poor democracies, political party development and other indicators of credibility in political systems are often weak. Parties have little history and no identifiable positions on issues. Individual candidates may be credible on one or two issue dimensions (e.g., religion), but rarely on the broad issues that define efficient government performance.

Researchers have taken two approaches to the analysis of non-credibility in electoral politics. In one, voters can coordinate on expost performance standards, as in Ferejohn

\footnotetext{
27 It could, for example, be the case that the mass media better enabled politicians to take credit for targeted payoffs to particular constituencies, leading them to reduce expenditures on public goods or on broad-based social programs.
} 
(1986) and Persson and Tabellini (2000), and reject incumbents that fail to meet them.

Politicians provide no targeted private goods. They underprovide public goods and engage in greater rent-seeking, relative to when they are fully credible. In the second, as in Robinson and Verdier (2002), voters cannot coordinate on such performance standards and no public goods are provided at all. In this case, challengers are irrelevant, since they are never credible, and incumbent performance has no effect on voter behavior.

Both approaches explain the poor provision of public goods in developing countries, including the rule of law and the security of property rights, but are at odds with another. They predict indifference on the party of politicians to the provision of targeted goods (except to voters from whose consumption candidates directly derive utility, as in Robinson and Verdier). However, in most developing country democracies, politicians are intensely concerned about delivering targeted transfers.

Keefer (2002b) suggests a third credibility scenario, rooted in the literature on clientelism that describes patron-client relationships as repeated, personalized interactions between patrons and clients. Based on such interactions, politicians can make credible promises to some voters but not to others. Repeated interaction constitutes a basis for reputation-building. Politicians with personalized reputations with some voters can make credible promises to those voters, even if to no others. In countries exhibiting "partial" credibility, the foundation of a politician's credibility is not based on the policy record of party or politician. Instead, voters believe the politicians who have, for example, shown themselves to be reliable sources of personal assistance. These might be locally influential people who have helped families with loans or jobs or assistance with legal or bureaucratic difficulties. In the absence of well-developed political parties or national party leaders who 
are more broadly credible to voters, the promises of such influential people are all that voters can rely on in making electoral choices. ${ }^{28}$

Partial credibility explains many of the policy outcomes observed in democracies that might be labeled less credible (or less developed in general). Since the only policy promises that matter prior to elections are those that "clients" believe, promises of private goods to clients are more politically attractive than public goods that benefit both clients and nonclients. Promises of public works and government jobs become the currency of political competition at the expense of universal access to high quality education and health care. The former can be targeted to individuals and small groups of voters (clients). Universal access is by definition not easily targeted. Corruption or rent-seeking is also high, since it is unlikely that individual voters have two "patrons"; as a consequence, most voters do not have politicians competing for their votes.

Keefer (2003a) documents that young democracies exhibit greater than average public investment (targeted infrastructure investment), less secondary school enrollment (non-targetable), less secure property rights and greater corruption. This pattern can be explained by the greater prevalence among young democracies of partially credible political actors. Young democracies are more likely to exhibit non-credible political parties and reliance among political competitors on clientelist promises to the small groups of voters to whom they can make credible promises.

The pre-electoral credibility of politicians is useful to examine not only because it seems to explain many of the policy failures observed in poor countries, but because it also explains why so few countries have managed to sustain long periods of economic growth

\footnotetext{
28 Stokes (2001) and contributors attempt to use public opinion polls to evaluate simultaneously the political impact of citizen information and political credibility, implicitly assessing whether citizens believe candidate promises, whether they use past performance to judge future actions of politicians, and how economic shocks influence their evaluation of candidates issue more finely.
} 
and prosperity. Reputations are fragile and difficult to develop. For example, as Keefer (2002b) argues, some countries (such as Great Britain or the United States), began their periods of democracy and a near universal franchise with political parties that had clearly established differences on issues ranging from religion to land reform and trade policy. This is not the experience of most countries. Instead, most parties need to start building reputations after democracy has started. For example, in the year 2000, the average age of political parties in half of the 96 countries in the Database of Political Institutions with competitive legislative and executive elections was less than 26 years. These were disproportionately poor. Unfortunately, the reputation-building process is fraught with multiple equilibria, many of which involve no reputation at all, or a reputation for policies that are probably irrelevant for development (valor in the battle for independence or religious righteousness).

\section{Conclusion}

The rich literature in political economy has vastly improved our ability to understand who wins and loses in the process of economic policy making. It has clearly shown the absence of any necessary connection between political decision making and efficiency or equity objectives, and offers explanations of frequent deviations of policy from the socially optimal that are not rooted in policy maker error or ignorance. Applied to developing countries, political economy analyses demonstrated that often catastrophic policy choices and living conditions do not result primarily from a shortage of resources or an oppressive international economic order, but rather to local political and social conditions and the distorted incentives with which these conditions endow government decision makers.

Theory and evidence suggest that development is not so much influenced by constitutional choices such as whether governments have presidential or parliamentary 
systems, or proportional or majoritarian electoral systems. Elections and the universal franchise appear to have similarly little impact on economic development. Instead, theory and evidence point to one type of institutional arrangement - elections cum political checks and balances - as important for growth and development.

Even among countries exhibiting these institutional arrangements, though, the range of development experiences is wide. Imperfections in electoral and political markets offer an explanation for this. Both the voter information and politician credibility differ substantially between developed and developing countries and explain why politicallyinduced development distortions are greater in some countries than others. At the same time, these imperfections explain why development is difficult to achieve. Reputation is difficult to build and subject to a multitude of possible adverse equilibria. It is, then, not surprising that politics so rarely supports sustained development.

Ample work remains. Of the many open issues, one of the most basic is that we do not know how reputation builds, even in successful countries. There is no analysis of the conditions under which politicians translate non-economic reputations (e.g., for successfully fighting colonial occupiers) into a reputation for pursuing growth-promoting policies. Evidence on the role of information in politics and development relies on newspaper circulation rather than direct measures of the "supply and demand" for voter information. The literature provides little insight as to how incomplete information affects the tradeoffs politicians make between public, non-targeted and private, targeted goods. The origins of an informed electorate are almost entirely unknown. All of these are relevant questions in every country, developed or not. However, it is in the examination of underdevelopment that their importance in a complete theory of political economy has become especially clear. 


\section{Literature Cited}

Acemoglu D, Robinson J. September 2001. "A Theory of Political Transitions." American Economic Review 91:4, 938-63

Acemoglu D, Johnson S, Robinson J. November 2002. "Reversal of Fortune: Geography and Institutions in the Making of the Modern World Income Distribution." Quarterly Journal of Economics 117:4, 1231-94

Adserà A, Boix C, Payne M. "Are you being served? Political accountability and governmental performance." Journal of Law, Economics and Organization. Forthcoming.

Alesina A, Drazen A. 1991. "Why are Stabilizations Delayed?” American Economic Review 81(5), 1170-1188

Ames B. 1995. "Electoral Rules, Constituency Pressures and Pork Barrel: Bases of Voting in the Brazilian Congress." The Journal of Politics 57:2, 324-43

Baron DP. March1994. "Electoral Competition with Informed and Uninformed Voters". American Political Science Review, 88, 33-47

Bates RH. 1981. Markets and States in Tropical Africa: the political basis of agricultural policies. Berkeley: University of California Press

Bates RH 1983. Essays on the Political Economy of Rural Africa. Cambridge: Cambridge University Press

Beck T, Clarke G, Groff A, Keefer P, Walsh P. 2001. "New Tools in Comparative Political Economy: The Database of Political Institutions." World Bank Economic Review, 15:1, 165-176

Besley T, Burgess R. 2003. "The Political Economy of Government Responsiveness: Theory and Evidence from India". Quarterly Journal of Economics, Forthcoming

Besley T, Coate S. January 2001. "Lobbying and Welfare in a Representative Democracy." Review of Economic Studies 68:1, 67-82

Bradbury JC, Crain MW. December 2001. "Legislative Organization and Government Spending: Cross-Country Evidence." Journal of Public Economics 82:3, 309-25

Broz L. 2002. "Domestic Politics of International Financial Rescues: Congressional Voting on Bailouts in the 1990s." Mimeo, Department of Political Science, University of California, San Diego

Cheibub JA, Limongi F. 2002. "Democratic Institutions and Regime Survival: Parliamentary and Presidential Democracies Reconsidered." Annual Review of Political Science 
Cox G. 1997. Making Votes Count: Strategic Coordination in the World's Electoral Systems. New York: Cambridge University Press

Cox G, McCubbins M. 1993. Legislative Leviathan: Party Government in the House. Berkeley: University of California Press

Cox G, McCubbins M. 2001. "The Institutional Determinants of Economic Policy Outcomes." In Presidents, Parliaments and Policy, Stephan Haggard and Mathew McCubbins, eds., 21-63. New York: Cambridge

Diermeier D, Fedderson T. 1998. "Cohesion in legislatures and the vote of confidence procedure.” American Political Science Review 92: 611-21

Engerman S, Sokoloff K. Fall 2002. "Factor Endowments, Inequality, and Paths of Development among New World Economies." Economia 3:1, 41-88

Ferejohn J. 1986. "Incumbent performance and electoral control." Public Choice 50: 5-26

Frieden Jeffry. A. 1991. Debt, Development and Democracy. Princeton: Princeton University Press

Grossman G, Helpman E. 1996. "Electoral competition and special interest politics". Review of Economic Studies 63, 265-286

Haggard S, McCubbins M. eds. 2001. Presidents, Parliaments and Policy. New York: Cambridge University Press

Hallerberg M, von Hagen J. 1999. "Electoral institutions, cabinet negotiations, and budget deficits in the European Union." In J Poterba and J von Hagen, eds. Fiscal Institutions and Fiscal Performance. Chicago: University of Chicago Press, 209-32

Hardin R. 1982. Collective Action. Baltimore: Johns Hopkins University Press.

Henisz W. March 2000. “The Institutional Environment for Economic Growth.” Economics and Politics 12:1, 1- 31

Huber J. September 1992. "Restrictive Legislative Procedures in France and the United States." The American Political Science Review 86:3, 675 - 687

Huber J. 1996. "The Vote of Confidence in Parliamentary Democracies." American Political Science Review 90: 2, 269-82

Jones MP, Pablo S, Tommasi M. April 2000. "Politics, institutions, and fiscal performance in a federal system: an analysis of the Argentine provinces." Journal of Development Economics 61:2, 305-333

Keefer P. 2002. "Clientelism, Credibility and Democracy." Mimeo, Development Research Group, The World Bank 
Keefer P. 2003a. "Democratization and Clientelism: Why are Young Democracies Badly Governed?" Mimeo. Development Research Group, The World Bank.

Keefer P. 2003b. "All Democracies are not the Same: Identifying the Institutions that Matter for Growth and Convergence." Paper presented at the conference "Successes and Failures of Real Convergence," October 23-24, National Bank of Poland, Warsaw.

Keefer P, Knack S. July 1997. “Why Don’t Poor Countries Catch Up? A Cross-national Test of an Institutional Explanation." Economic Inquiry 35: 590-602

Keefer P, Knack S. 2002a. "Boondoggles and Expropriation: Rent-seeking and Policy Distortion when Property Rights are Insecure.” Policy Research Working Paper 2910, The World Bank

Keefer P, Knack S. 2002b. "Social Polarization, Political Institutions and Country Creditworthiness." In Collective Choice: Essays in Honor of Mancur Olson, Dennis Coates and Jac Heckelman, eds. New York: Springer Verlag, 165 - 186

Keefer P, Stasavage D. 2002. "Checks and Balances, Private Information and the Credibility of Monetary Commitments.” International Organization, 56:4, 751-774. Fall.

Keefer P, Stasavage D. 2003. “The Limits of Delegation: Veto Players, Central Bank Independence, and the Credibility of Monetary Policy." American Political Science Review, 97:3, 407-423.

Krehbiel K. 1991. Information and Legislative Organization. Ann Arbor: University of Michigan Press.

Krehbiel K. 1996. "Committee Power, Leadership, and the Median Voter: Evidence from the Smoking Ban." Journal of Law, Economics and Organization 12:1, 234 - 56 (April).

Kroszner RS, Stratmann T. 1998. "Interest Group Competition and the Organization of Congress." American Economic Review 88:5, 1163-1187 (December).

Kroszner RS, Strahan PE. 1999. Quarterly Journal of Economics 114:4 1437-67

Linz J J, Valenzuela A. 1996. The Failure of Presidential Democracy. Baltimore: Johns Hopkins University Press.

Mainwaring S. 1997. "Multipartism, Robust Federalism, and Presidentialism in Brazil." In Mainwaring and Shugart, eds., Presidentialism and Democracy in Latin America. New York: Cambridge University Press, 55 - 109

Mainwaring S, Soberg Shugart M. 1997. Presidentialism and Democracy in Latin America. New York: Cambridge University Press.

Mani A, Mukand S. 2002. "Democracy, Visibility and Public Good Provision.” Mimeo. Williams College and Tufts University. 
McGuire RA, Ohsfeldt RL. March 1986. “An Economic Model of Voting Behavior over Specific Issues at the Constitutional Convention of 1787." The Journal of Economic History 46:1 79-111

McMillan M. February 2001. "Why Kill the Golden Goose? A Political-Economy Model of Export Taxation." Review of Economics and Statistics 83:1, 170-84

Mulligan C, Gil R, Sala-i-Martin X. October 2003. "Do Democracies have Different Public Policies than Non-democracies?" National Bureau of Economic Research Working Paper 10040

North D. 1981. Structure and Change in Economic History. New York: Norton.

North D, Weingast B. 1989. "Constitutions and Commitment: The Evolution of Institutions Governing Public Choice in Seventeenth-Century England.” Journal of Economic History 49 (December): 803 - 32

Olson M. 1965. The Logic of Collective Action: Public Goods and the Theory of Groups. Cambridge: Harvard University Press

Olson M. 1982. The Rise and Decline of Nations. New Haven: Yale University Press

Persson, T, Roland G, Tabellini G. 2000. "Comparative Politics and Public Finance." The Journal of Political Economy 108:6, 1121-1161 (December).

Persson T, Tabellini G. 1999. "The Size and Scope of Government: Comparative Politics with Rational Politicians." European Economic Review 43: 699-735

Persson T. 2000. Political Economics: Explaining Public Policy. Cambridge, MA: The MIT Press

Persson T, Trebbi F. 2003. "Electoral Rules and Corruption." Journal of the European Economic Association 1:4, 958-89

Pritchett L. 1997. “Divergence, Big Time.” Journal of Economic Perspectives 11:3, 3-17

Przeworski A, Alvarez ME, Cheibub JA, Limongi F. 2000. Democracy and Development: Political Institutions and Well-Being in the World, 1950-1990. Cambridge: Cambridge University Press

Rueschmeyer D, Huber Stephens E, Stephens JD. 1992. Capitalist Development and Democracy. Chicago: University of Chicago Press

Robinson J, Verdier T. 2002. “The Political Economy of Clientelism.” CEPR Working Paper 3205

Romer T, Weingast B. 1991. "The Political Foundations of the Thrift Debacle." In Alberto Alesina and Geoffrey Carliner, eds., Politics and Economics in the Eighties. Chicago: University of Chicago Press. 
Samuels D and Snyder R 2001. "The Value of a Vote: Malapportionment in Comparative Perspective." British Journal of Political Science 31:3, 651-71 (Fall).

Seddon JW, et al. 2003. "Particularism Around the World." World Bank Economic Review 17:1, $133-43$.

Shepsle K and Weingast B. 1987. "The Institutional Foundations of Committee Power." American Political Science Review 81:1, 85-104 (March).

Shepsle K and Weingast B. 1994. "Positive Theories of Congressional Institutions." Legislative Studies Quarterly, 19:2, 149 - 179 (May).

Shleifer A, et al. 2003. "The New Comparative Economics.” Institute for Economic Research, Harvard University, Discussion Paper No. 2002 (July).

Shugart MS and Carey J. 1992. Presidents and Assemblies: Constitutional Design and Electoral Dynamics. Cambridge: Cambridge University Press.

Shugart MS and Haggard S. 2001. "Institutions and Public Policy in Presidential Systems." In Haggard S and McCubbins M, eds., Presidents, Parliaments and Policy. New York: Cambridge University Press, 64 -104.

Shugart MS and Mainwaring S. 1997. "Presidentialism and Democracy in Latin America: Rethinking the Terms of the Debate." In Mainwaring S and Shugart MS, eds. Presidentialism and Democracy in Latin America, 12-54. New York: Cambridge University Press.

Stasavage D. 2003. Public Debt and the Birth of the Democratic State: France and Great Britain 16881789. New York: Cambridge University Press.

Stokes SC. 2001. Public Support for Market Reforms in New Democracies. New York: Cambridge University Press.

Strömberg D. 2001. "Radio's Impact on New Deal Spending", mimeo, Princeton University.

Sussman N and Yafeh Y. 2002. "Constitutions and Commitment: Evidence on the Relation between Institutions and the Cost of the Capital." Mimeo, The Hebrew University of Jerusalem and Social Sciences Research Network.

Tsebelis G. 1995. "Decision Making in Political Systems: Veto Players in Presidentialism, Parliamentarism, Multicameralism and Multipartyism." British Journal of Political Science 25 (3): 289-325. 